\title{
Ovarian cancer of endometrioid type as part of the MSH6 gene mutation phenotype
}

Received: June 10, 2002 / Accepted: June 27, 2002

\begin{abstract}
The MSH6 gene is one of the DNA mismatch repair genes involved in development of inherited cancers, predominantly of the colorectum and endometrium. Herein we describe the first Polish MSH6 family and the pathological and clinical data about the ovarian cancer diagnosed in the proband. Our results and reports by others indicate that, besides colorectal and endometrial cancer, the late-onset endometrioid type of ovarian cancer can be a feature of families with MSH6 germline mutations.
\end{abstract}

Key words $M S H 6$ - Endometrioid type · Ovarian cancer · Endometrial cancer · Colon cancer · Germline mutation

\section{Introduction}

The MSH6 gene, along with MLH1, MSH2, PMS2, MLH3, and $E X O 1$, belongs to a group of DNA mismatch repair genes, which, when mutated, cause development of inherited cancers mainly in the colon, rectum, and endometrium (Kurzawski et al. 2002; Debniak et al. 2000; Nicolaides et al. 1994; Wu et al. 2001a; Wu et al. 2001b; Akiyama et al. 1997).

The MSH6 gene has been mapped on chromosome 2 (2p15-16) and is transcribed as a 4245-bp mRNA encoding a $153-\mathrm{kDa}$ protein of 1360 amino acids. This MSH6 protein contains two domains that allow interaction with the $\mathrm{MSH} 2$ protein. Biochemical studies indicate that the $\mathrm{MSH}_{2}$ MSH6 complex recognizes base-base mispairs and small insertion-deletion loops (Guerrette et al. 1998; Acharya et al. 1996).

Studies of affected individuals with MSH6 germline mutations indicate that the clinical phenotype is often different

J. Suchy $(\bowtie) \cdot$ G. Kurzawski $\cdot$ A. Jakubowska $\cdot$ J. Lubiński Hereditary Cancer Center, Department of Genetics and Pathology, Pomeranian Academy of Medicine, ul. Polabska 4, Szczecin 70-115, Poland

Tel./Fax +48-91-4661533

e-mail: jansuch@interia.pl from phenotypes observed in classical hereditary nonpolyposis colorectal cancer (HNPCC), which is caused by mutations in the $M L H 1$ and $M S H 2$ genes (Akiyama et al. 1997). Generally, MSH6 families are characterized by later age of onset of the disease, and cancers of affected individuals exhibit low levels of instability mostly at mononucleotide repeats (Wijnen et al. 1999).

Pedigrees of MSH6 families present a predominance of colorectal and endometrial cancers, as do $M S H 2 / M L H 1$ families. Carriers of $M S H 2 / M L H 1$ and $M S H 6$ mutations can also be affected by malignancies at different sites including the ovary. In $M S H 2 / M L H 1$ mutation carriers, most ovarian tumours are serous and endometrioid carcinomas, usually well or moderately differentiated, and diagnosed at an early age of $\sim 43$ years (Watson et al. 2001). Histological data concerning ovarian cancer in MSH6 mutation carriers has been reported in one case only (Wagner et al. 2001). We now report pathological and clinical data concerning an additional case of ovarian cancer in an MSH6 family.

\section{Subjects and methods}

The pedigree of the MSH6 family is presented in Fig. 1. The proband (III-3), a 49-year-old woman with bilateral endometrioid ovarian cancer, had a positive family history of cancers. Her father died of colon cancer at the age of 83 years and her paternal grandmother died of endometrial cancer at the age of 69 years. Endometrial cancer was diagnosed at the age of 57 years in her cousin, who is at present 68 years old. Initial molecular analyses were performed on proband III-3. DNA was extracted from peripheral blood, and sequencing of all coding fragments of the $\mathrm{MSH} 2$ and $M L H 1$ genes did not reveal mutation. The proband DNA was then analyzed for MSH6 changes.

In exon 5 of the MSH6 gene, we identified a frameshift mutation 3311-3312 delTT, which creates a termination codon at 1106 and removes the carboxy-terminal MSH2 interaction region and the nucleotide binding region (Guerrette et al. 1998). 
Fig. 1. Pedigree of the MSH6 family. $E$, Endometrial cancer; $R$, rectal cancer; $O v$, ovarian cancer; Liv, liver cancer. The numbers following abbreviations indicate the age at diagnosis; $(+)$, MSH6mutation positive; (-), MSH6mutation negative. Arrow indicates the proband

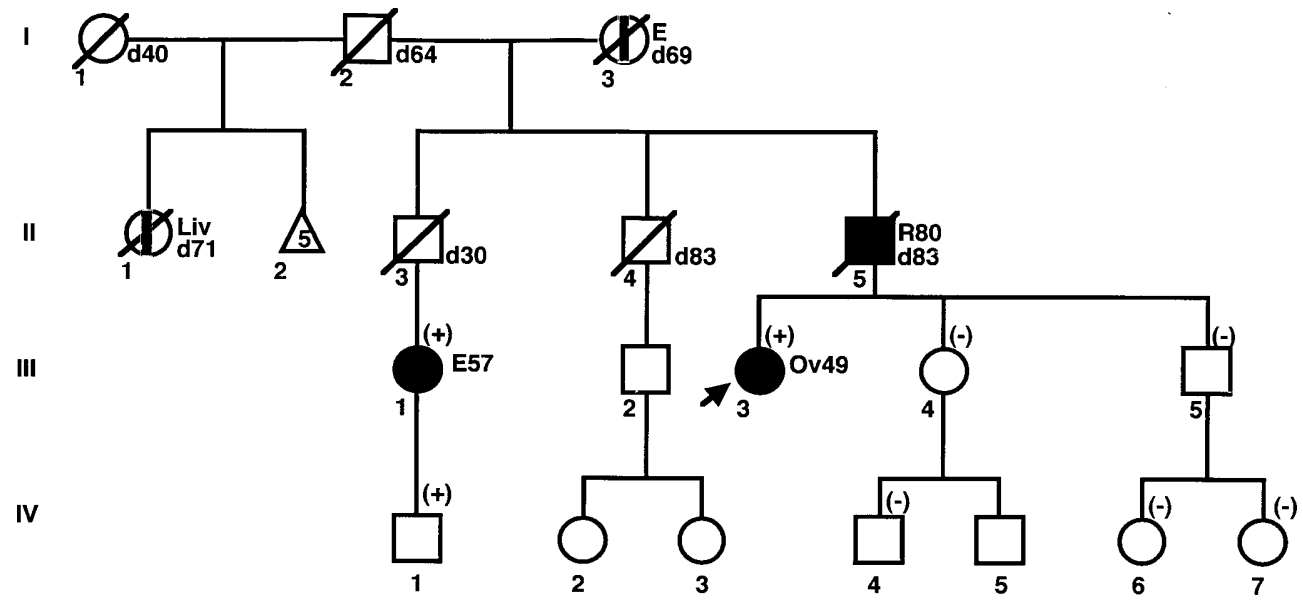

The proband and family members were informed about the findings and were invited to be tested for the presence of the mutation. DNA testing for this mutation was performed in seven living relatives, three male relatives and five female relatives. Two relatives with a previously diagnosed HNPCC-related tumour (III-1, III-3) and one unaffected relative (IV-1) were carriers. Other relatives were negative for the MSH6 mutation (III-4, III-5, IV-4, IV-6, IV-7). The histopathological and clinical data of the proband were independently verified. Her current age is 63 years and she was diagnosed at age 49 years as having bilateral ovarian cancers of the endometrioid type with morphological malignancy grade $\mathrm{G} 1 / 2$ and clinical stage I/II, according to the International Federation of Gynecology and Obstetrics (FIGO).

\section{Results and discussion}

This case study of histologically verified ovarian cancers in an MSH6 carrier, as well as that previously reported (Wagner et al. 2001) are of endometrioid type. Thus, ovarian cancers of this type may be characteristic of MSH6 mutation carriers; such cancers have also been reported as characteristic in HNPCC cases (Watson et al. 2001). A potential difference between such cancers in $M L H 1 / M S H 2$ and MSH6 mutation carriers may be the age at diagnosis. The average age at diagnosis of ovarian cancers in MSHO mutation carriers is 48 years, whereas these tumors in $M S H 2 / M L H 1$ mutation carriers were diagnosed at an average age of 43 years.

Later age at diagnosis of cancers may be a major feature useful in differential diagnosis in $M S H 2 / M L H 1$ and $M S H 6$ families because colorectal and endometrial cancers also occur at a later age in MSH6 mutation carriers: 53 vs 43 years and 55 vs 48.5 years, respectively. In approximately $20 \%$ of families with the MSH6 mutation, cancers appear at $\geq 50$ years of age, despite the fact that MSH6 mutation analyses were performed frequently, if not consecutively, in those cases that showed Amsterdam criteria and were negative for MSH2/MLH1 (Akiyama et al. 1997; Wu et al. 1999;
Wagner et al. 2001; Wijnen et al. 1999; Kolodner et al. 1999; Miyaki et al. 1997; Plaschke et al. 2000; Huang et al. 2001; Berends et al. 2002; Plaschke et al. 2002; Verma et al. 1999).

In summary, it may be worthwhile to develop studies to assess whether later onset of endometrioid ovarian cancer is characteristic of carriers with MSH6 constitutional mutations.

Acknowledgments We are grateful to the family members for giving their informed consent to participate in this study and to Professor K. Huebner for critical remarks on the manuscript. This work was supported by grants IC15-CT98-0305 and QLRI-CT-1999-00063 from the European Commission. Janina Suchy is the recipient of a scholarship from the Postgraduate School of Molecular Medicine funded by the Medical University of Warsaw.

\section{References}

Acharya S, Wilson T, Gradia S, Kane MF, Guerrette S, Marsischky GT, Kolodner R, Fishel R (1996) $h M S H 2$ forms specific mispairbinding complexes with $h M S H 3$ and $h M S H 6$. Proc Natl Acad Sci USA 93:13629-13634

Akiyama Y, Sato H, Yamada T, Nagasaki H, Tsuchiya A, Abe R, Yuasa Y (1997) Germ-line mutation of the $h M S H 6 / G T B P$ gene in an atypical hereditary nonpolyposis colorectal cancer kindred. Cancer Res 57:3920-3923

Berends MJW, Wu Y, Sijmons RH, Mensink RGJ, van der Sluis T, Hordiik-Hos JM, deVries EGE, Hollema H, Karrenbeld A, Buys CH, van der Zee AGJ, Hofstra RMW, Kleibeuker JH (2002) Molecular and clinical characteristics of MSH6 variants: an analysis of 25 index carriers of a germline variant. Am J Hum Genet 70:26-37

Debniak T, Kurzawski G, Gorski B, Kladny J, Domagala W, Lubinski $\mathbf{J}$ (2000) Value of pedigree/clinical data, immunohistochemistry and microsatellite instability analyses in reducing the cost of determining $h M L H 1$ and $h M S H 2$ gene mutations in patients with colorectal cancer. Eur J Cancer 36:49-54

Guerrette S, Wilson T, Gradia S, Fishel R (1998) Interactions of human $h M S H 2$ with $h M S H 3$ and $h M S H 2$ with $h M S H 6$ : examination of mutations found in hereditary nonpolyposis colorectal cancer. Mol Cell Biol 18:6616-6623

Huang J, Kuismanen SA, Liu T, Chadwick RB, Cheryl KJ, Stevens MW, Richards SK, Meek JE, Gao X, Wright FA, Mecklin JP, Järvinen HJ, Grönberg H, Bisgaard ML, Lindblom A, Peltomäki P (2001) MSH6 and MSH3 are rarely involved in genetic predisposition to nonpolypotic colon cancer. Cancer Res 61:1619-1623

Kolodner RD, Tytell JD, Schmeits JL, Kane MF, Gupta RD, Weger J, Wahlberg S, Fox EA, Peel D, Ziogas A, Garber JE, Sygnal S, Anton- 
Culver H, Li FP (1999) Germ-line MSH6 mutations in colorectal cancer families. Cancer Res 59:5068-5074

Kurzawski G, Suchy J, Kładny J, Safranow K, Jakubowska A, Elsakow P, Kucinskas V, Gardovski J, Irmejs A, Sibul H, Huzarski T, Byrski T, Dębniak T, Cybulski C, Gronwald J, Oszurek O, Clark J, Góźdź S, Niepsuj S, Słomski R, Pławski A, Łącka-Wojciechowska A, Rozmiarek A, Fiszer-Maliszewska Ł, Bębenek M, Sorokin D, Stawicka M, Godlewski D, Richter P, Brożek I, Wysocka B, Jawień A, Banaszkiewicz Z, Kowalczyk J, Czudowska D, Goretzki P, Moeslein G, Lubiński J (2002) Germline MSH2 and MLH1 mutational spectrum in HNPCC families from Poland and Baltic States. J Med Genet (in press)

Miyaki M, Konishi M, Tanaka K, Kikuchi-Yanoshita R, Muraoka M, Yasuno M, Igari T, Koike M, Chiba M, Mori T (1997) Germline mutation of MSH6 as the cause of hereditary nonpolyposis colorectal cancer. Nat Genet 17:271-272

Nicolaides NC, Papadopoulos N, Liu B, Wei YF, Carter KC, Ruben SM, Rosen CA, Haseltine WA, Fleischmann RD, Fraser CM, Adams MD, Venter JC, Dunlop MG, Hamilton SR, Petersen GM, de la Chapelle A, Vogelstein B, Kinzler KW (1994) Mutations of two $P M S$ homologues in hereditary nonpolyposis colon cancer. Nature 371:75-80

Plaschke J, Kruppa Ch, Tischler R, Bocker T, Pistorius S, Dralle H, Rüschoff J, Saeger HD, Fishel R, Schackert HK (2000) Sequence analysis of the mismatch repair gene hMSH6 in the germline of patients with familial and sporadic colorectal cancer. Int $\mathbf{J}$ Cancer 85:606-613

Plaschke J, Krüger S, Pistorius S, Theissig F, Saeger HD, Schackert HK (2002) Involvement of $h M S H 6$ in the development of hereditary and sporadic colorectal cancer revealed by immunostaining is based on germline mutations, but rarely on somatic inactivation. Int J Cancer 97:643-648

Verma L, Kane MF, Brassett C, Schmeits J, Evans DGR, Kolodner RD, Maher ER (1999) Mononucleotide microsatellite instability and germline mutations analysis in early onset colorectal cancer. J Med Genet 36:678-682

Wagner A, Hendriks Y, Meijers-Heijboer EJ, de Leeuw WJF, Morreau H, Hofstra R, Tops C, Bik E, Bröcker-Vriends AHJT, van der Meer $\mathrm{C}$, Lindhout D, Vasen HFA, Breuning MH, Cornelisse CJ, van Krimpen C, Niermeijer MF, Zwinderman AH, Wijnen J, Fodde R (2001) Atypical HNPCC owing to MSH6 germline mutations: analysis of a large Dutch pedigree. J Med Genet 38:318-322

Watson P, Bützow R, Lynch HT, Mecklin JP, Järvinen HJ, Vasen HFA, Madlensky L, Fidalgo P, Bernstein I, International Collaborative Group on HNPCC (2001) The clinical features of ovarian cancer in hereditary nonpolyposis colorectal cancer. Gynecol Oncol 82:223228

Wijnen $\mathrm{J}$, de Leeuw $\mathrm{W}$, Vasen $\mathrm{H}$, van der Klift $\mathrm{H}$, Møller $\mathrm{P}$, Stormorken A, Meijers-Heijboer H, Lindhout D, Menko F, Vossen S, Möslein G, Tops C, Bröcker-Vriends A, Wu Y, Hofstra R, Sijmons R, Cornelisse C, Morreau H, Fodde R (1999) Familial endometrial cancer in female carriers of MSH6 germline mutations. Nat Genet 23:142-144

Wu Y, Berends MJW, Mensink RGJ, Kempinga C, Sijmons RH, van der Zee AGJ, Hollema H, Kleibeuker JH, Buys CH, Hofstra RMW (1999) Association of hereditary nonpolyposis colorectal cancerrelated tumors displaying low microsatellite instability with MSH6 germline mutations. Am J Hum Genet 65:1291-1298

Wu Y, Berends MJ, Sijmons RH, Mensink RG, Velind E, Kooi KA, van der Sluis T, Kempinga $C$, van der Zee AG, Hollema $H$, Buys $\mathrm{CH}$, Kleibeuker JH, Hofstra RMW (2001a) A role for $M L H 3$ in hereditary nonpolyposis colorectal cancer. Nat Genet 29:137-138

Wu Y, Berends MJ, Post JG, Mensink RG, Verlind E, van der Sluis T, Kempinga C, Sijmons RH, van der Zee AG, Hollema H, Kleibeuker JH, Buys CH, Hofstra RM (2001b) Germline mutations of EXO1 gene in patients with hereditary nonpolyposis colorectal cancer (HNPCC) and atypical HNPCC forms. Gastroenterology 120:15801587 